\title{
HIPERTENSI DAN PENGARUHNYA TERHADAP ORGAN-ORGAN TUBUH
}

\author{
Oleh: dr. Moch Noerhadi
}

Dosen Jurusan Pendidikan Kesehatan dan Rekreasi FIK UNY

\section{ABSTRAK}

Hipertensi adalah tekanan darah dimana sistolenya setinggi $165 \mathrm{mmHg}$ atau lebih sedangkan diastole nya mencapai $95 \mathrm{mmHg}$ atau lebih. Pengaruh hipertensi pada organ tubuh atau organ target dianggap sebagai peninggian tekanan darah. Hipertensi dapat menyebabkan keruskan pada sel-sel epitel tunika intima arteri yang berakibat atau merangsang terjadinya atherosclerosis dan thrombus. Sedangkan organ target yang terkena adalah jantung, otak, ginjal dan mata.

Perawatan hipertensi dibedakan atas terapi tanpa obat dan terapi dengan obat. Terapi tanpa obat digunakan sebagai tindakan definitif untuk hipertensi ringan dan sebagai tindakan suportif pada hipertensi sedang dan berat.

Kata Kunci: hipertensi, organ tubuh

Hipertensi merupakan masalah kesehatan yang perlu untuk diketahui oleh masyarakat umum, karena angka prevalensi yang tinggi serta akibat jangka panjang yang ditimbulkannya mempunyai konsekuensi tertentu. Selain itu hipertensi banyak dijumpai dalam praktek sehari-hari. Sejalan dengan

MEDIKORA Vol. IV, No 2, Oktober 2008: 1-18 
kemajuan dan modernisasi kejadian hipertensi akan meningkat terus, bahkan data-data menunjukkan bahwa dewasa ini lebih kurang 10\% penduduk Indonesia menderita hipertensi dimana sebagian besar dari penderita tidak diketahui penyebab hipertensinya.

Kerusakan organ tubuh akibat hipertensi seperti penyakit jantung koroner dan perdarahan otak merupakan penyebab utama kematian pada penderita hipertensi. Menurut Kaplan, studi Framingham menunjukkan bahwa penderita hipertensi laki-laki tua di atas 65 tahun akan mendapat 2-3 kali kemungkinan penyakit jantung koroner dengan kematian $50 \%$ dalam waktu 5 tahun dan 6 kali mendapatkan stroke dibandingkan dengan orang yang normotensi.

Selain penyakit jantung banyak kerugian yang diderita manusia akibat hipertensi misalnya kegagalan ginjal, kerusakan pada mata, kelumpuhan akibat serangan pada otak. Menurut Moerdowo (1984), 7\% dari wanita hamil menderita toksemia gravidarum yang ditandai dengan adanya hipertensi berat, proteinuria dan udema kaki. Penyakit ini berakibat fatal bagi ibu dan anak yang dikandungnya.

Peneltian Randy Eicner (dikutip Ezra, 1994; 38) menemukan penderita hipertensi berat pada atlit angkat 
berat. Hal ini sangat merepotkan latihannya karena adanya resiko terjadinya perdarahan intracranial pada waktu melakukan latihan angkat berat.

\section{PEMBAHASAN}

\section{Pengertian Hipertensi}

Hipertensi berasal dari kata Latin hyper yang berarti super atau luar biasa, dan kata Latin tensio yang berarti tegangan atau tekanan sehingga diartikan tekanan yang luar biasa dan sekarang terkenal dengan nama tekanan darah tinggi atau hipertensi.

Menurut Sidabutar (dikutip Soeparman, 1990;205), hipertensi didefinisikan sebagai suatu tingkat tekanan darah dimana komplikasi yang timbul menjadi nyata. Sedangkan menurut WHO, hipertensi adalah tekanan darah dimana sistolenya setinggi $165 \mathrm{mmHg}$ atau lebih sedangkan diastole nya mencapai $95 \mathrm{mmHg}$ atau lebih.

The Joint National Committee on Detection, Evaluation, dan Treatment of High Blood Pressure 1984 mengklasifikasikan hipertensi atas dasar tekanan sistolik dan diastoliknya (dikutip Boedhi Darmojo, 1989;43).

MEDI KORA Vol. IV, No 2, Oktober 2008: 1-18 


\begin{tabular}{|ll|}
\hline Tekanan sistolik $(\mathrm{mHg})$ & Kategori \\
\hline$<140$ & Tekanan darah normal \\
$140-159$ & Hipertensi perbatasan \\
160 ke atas & Hipertensi sistolik \\
\hline
\end{tabular}

\begin{tabular}{|ll|}
\hline Tekanan diastolic $(\mathrm{mmHg})$ & Kategori \\
\hline$<85$ & Tekanan darah normal \\
$85-89$ & Tekanan darah normal tinggi \\
$90-104$ & Hipertensi ringan \\
$105-114$ & Hipertensi sedang \\
$>115$ & Hipertensi berat \\
\hline
\end{tabular}

Berdasarkan penyebabnya hipertensi dibagi dua yaitu :

1. Hipertensi primer (hipertensi esensial) yaitu hipertensi yang tidak diketahui penyebabnya, lebih dari 90\% penderita hipertensi tidak diketahui sebabnya (Soeparman, $1987 ; 318)$.

2. Hipertensi sekunder yaitu hipertensi yang diketahui penyebabnya. Ada beberapa faktor yang berhubungan dengan hipertensi sekunder, antara lain: a. Penyakit ginjal (GNA, gagal ginjal); b. Gangguan pada pembuluh darah ginjal; c. Kontrasespsi oral; d. Kehamilan; e. Kelainan hormonal; f. Stres berat; g. Tumor otak. 


\section{Patogenesis Hipertensi}

Sampai sekarang pengetahuan tentang hipertensi terus berkembang, karena masih belum ada jawaban yang memuaskan mengenai keterangan tentang hipertensi. Tekanan darah dipengaruhi oleh curah jantung dan tahanan perifer, segala sesuatu yang dapat mempengaruhi curah jantung dan tahanan perifer dapat mempengaruhi tekanan darah seseorang. Selain itu ada beberapa faktor yang dapat pula mempengaruhi tekanan darah misalnya faktor genetik, ginjal, faktor renin, angiotensin, aldosteron dapat dibuktikan berperan dalam peningkatan tekanan darah.

Sebelum kita uraikan lebih lanjut perlu kita lihat mekanisme-mekanisme dalam tubuh yang mengatur tekanan darah. Menurut Murdowo (1984) dalam tubuh manusia ada beberapa pengatur tekanan darah yaitu :

1. Mekanisme baroreseptor

2. Mekanisme kemoreseptor

3. Respon iskhemik dari pusat susunan syaraf

4. Mekanisme Renin-Angiotensin-Vasokonstriktor

5. Mekanisme Stress-Relaksasi

6. Mekanisme Ginjal dan Cairan Tubuh

7. Mekanisme Aldosteron 
Tahun 1834 Goldblatt dan kawan-kawan dapat menimbulkan tekanan tekanan darah yang naik dengan cara menjepit sebagian arteria renalis. Pada tahun 1939 Byrom dan Wilson berhasil menimbulkan tekanan darah tinggi dengan jalan menjepit salahsatu dari arteria renalis dan dapat pula menunjukkan terjadinya perubahan secara sekunder pada pembuluh-pembuluh darah ginjal yang sebelahnya, yang tidak mengalami penjepitan.

Dari keterangan di atas dapat disimpulkan bahwa adanya jepitan arteria renalis akan terjadi iskhemik pada ginjal yang menimbulkan tekanan darah tinggi, sedangkan pada ginjal yang lainnya juga terjadi iskhemik dan kerusakan pada arteri-arterinya. Hal ini akan menimbulkan adanya hipertensi yang terus-menerus walaupun penjepitan pada arteri renalis akhirnya dilepaskan.

Adanya iskhemik ginjal menyebabkan ginjal memproduksi zat renin secara berlebihan. Renin akan bekerja sebagai enzim terhadap renin substrat yang disebut angiotensinogen suatu protein yang dikeluarkan oleh sel-sel hati dan membentuk angiotensin I yang kemudian dihidrolisis oleh enzim-enzim tertentu menjadi angiotensin II.

Angiotensin II mempunyai kasiat yang sangat kuat terhadap:

Hipertensi dan Pengaruhnya Terhadap Organ-Organ.. (dr. Moch Noerhadi) 
1. Terjadinya vasokonstriksi pembuluh darah.

2. Mempengaruhi kelenjar adrenal untuk mengeluarkan hormon aldosteron. Hormon ini berpengaruh pada reabsorbsi Natrium menjadi berlebihan yang dapat mempengaruhi volume darah. Adanya vasokonstriksi dan volume darah akan mempengaruhi tekanan darah.

3. Mempengaruhi susunan syaraf outonom yaitu pacuan pada syaraf simpatis hingga terjadi vasokonstruksi pembuluh darah.

Kelenjar adrenal kemungkinan mempunyai peranan penting dalam patogenesis hipertensi primer dengan mekanisme yang belum bisa diterangkan, tetapi pada hipertensi sekunder kelenjar adrenal memegang peran yang sangat penting misalnya pada tumor Pheochromositoma dan Chusing sindroma. Pada penderita Pheochromositoma terdapat tumor yang tumbuh berasal dari sel-sel kromafin dari medulla kelenjar adrenal dan sel-sel kromafin ekstra adrenal. Karena sel-sel kromafin ini merupakan tempat sintesa dari katekolamin (epinefrin dan norepinefrin) maka gejala-gejala yang ditimbulkan tergantung dari kadar katekolamin yang diproduksi. Bila banyak epinefrin yang dikeluarkan maka akan timbul hipertensi sistolik, sedangkan bila yang diproduksi lebih banyak norepinefrin maka gejala

MEDIKORA Vol. IV, No 2, Oktober 2008: 1-18 
yang timbul adalah hipertensi sistolik dan diastolic. Cushing sindrom merupakan rangkaian gejala yang terjadi akibat dikeluarkannya hormon kortisol secara berlebihan oleh korteks adrenal yang berakibat terjadinya retensi natrium dan air serta timbulnya hipertensi. Pengeluaran kortisol secara berlebihan ini akibat adanya tumor pada kelenjar adrenal. Selain hipertensi pada penderita Cushing sindrom juga ditandai dengan timbunan lemak pada perut, pundak, tubuh bagian tengah, osteoporosis dan perdarahan-perdarahan bawah kulit.

\section{Gejala Klinik Hipertensi}

Menurut Soen I Siauw hampir sepertiga dari penderita hipertensi tidak menunjukkan gejala apapun selama sepuluh sampai duapuluh tahun dan biasanya baru diketahui pada waktu diadakan general check up.

Suparman berpendapat bahwa gejala yang timbul karena hipertensi dapat berbeda-beda tergantung dari tinggi rendahnya tekanan darah. Kadang-kadang hipertensi berjalan tanpa gejala, baru timbul gejala, bila telah terjadi bila telah terjadi komplikasi pada organ target seperti ginjal, jantung, otak dan mata.

Gejala-gejala hipertensi yang sering timbul adalah sakit kepala yang bervariasi dari ringan sampai berat, pusing 
kadang-kadang disertai rasa mual sampai muntah, nyeri tengkuk dan kepala bagian belakang merupakan keluhan yang sering dijumpai terutama waktu bangun tidur dipagi hari, nyeri otot dan sendi, insomnia, badan merasa lemah dan berdebar-debar. Pada umumnya gejala-gejala ini dapat timbul sepintas dan hilang timbul sehingga penderita tidak begitu mempersoalkannya atau bahkan tidak mempersulikannya, dianggap sebagai gejala masuk angina (pendapat orang awam). Tetapi bila sakitnya semakin meningkat dan terusmenerus, hal ini tidak dapat diabaikan dan harus dicari sebabnya mengapa.

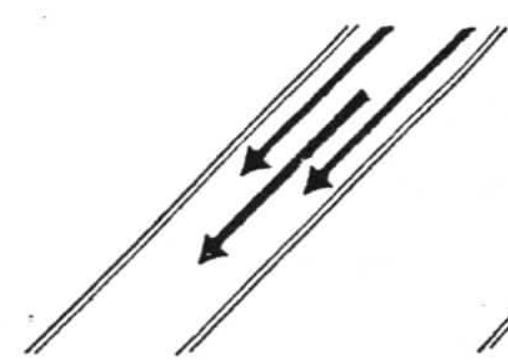

Normal flow

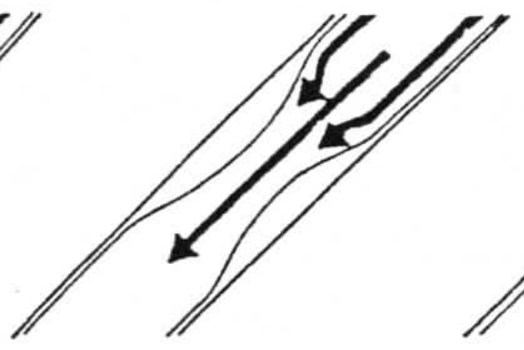

Narrowing

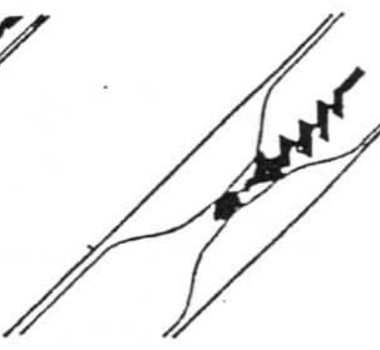

Clot formed

Gambar 1: Aterosklerosis

(Dikutip dari: Fox, 1986: 51) 


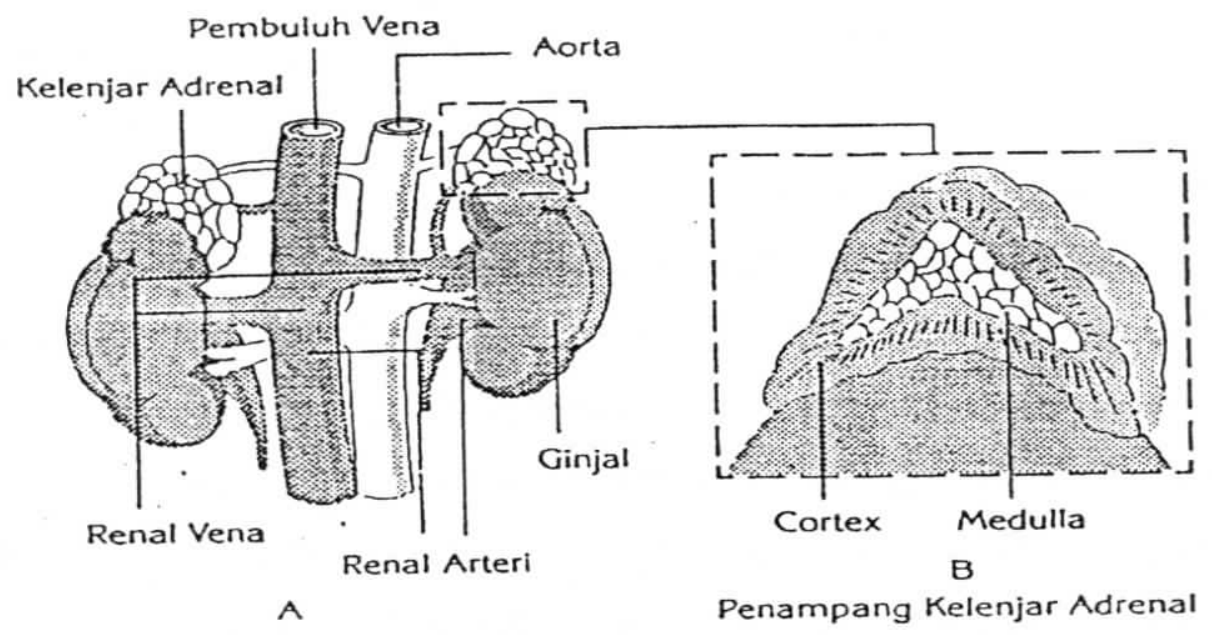

\section{Gambar 2. Kelenjar Adrenal}

(Dikutip dari: Soen I Siauw, 1994: 60)

\section{Pengaruh Hipertensi Pada Organ Tubuh}

Pengaruh hipertensi pada organ tubuh atau organ target dianggap sebagai peninggian tekanan darah. Hipertensi dapat menyebabkan keruskan pada sel-sel epitel tunika intima arteri yang berakibat atau merangsang terjadinya atherosclerosis dan thrombus. Sedangkan organ target yang terkena adlaah jantung, otak, ginjal dan mata.

\section{Pengaruh Hipertensi Terhadap Jantung}

Ada beberapa kelainan pada jantung sebagai akibat pengaruh hipertensi yaitu : 
Hipertrofi ventrikel kiri. Hal ini merupakan adaptasi otot jantung terhadap peningkatan beban kerja jantung. Pada keadaan hipertensi yang terus-menerus tanpa terjadi penurunan, pekerjaan otot jantung dalam berkontraksi menjadi lebih berat. Hal ini menyebabkan terjadinya hipertrofi miokradium ventrikel kiri karena ventrikel kiri menyangga beban paling berat dalam kerjanya memompa darah keseluruh tubuh. Untuk mengatassi tahanan perifer yang meningkat, ventrikel kiri mengalami hipertrofi. Dengan bertambahnya masaa otot jantung, sedangkan pasokan oksigen tetap maka terjadilah keadaan iskhemik yang relatif pada otot jantung. Sebagai akibat dari keadaan ini daya kekuatan kontraksi otot jantung menjadi berkurang. Pada suatu saat akan terjadi dilatasi ventrikel kiri sebagai usaha dari jantung untuk berkompensasi terhadap keadaan tersebut di atas. Sebagai akibat selanjutnya terjadilah keadaan yang disebut dekompensasi jantung kiri, dan bila hal ini berlanjut maka akan diikuti hipertrofi dan dilatasi ventrikel kanan yang akhirnya jantung kananpun mengalami dekompensasi. Selain itu hipertensi merupakan faktor resiko primer untuk terjadinya penyakit jantung koroner.

MEDIKORA Vol. IV, No 2, Oktober 2008: 1-18 


\section{Pengaruh hipertensi pada otak}

Hipertensi dapat menyebabkan pengaruh terhadap otak dengan menimbulkan aterosklerosis pada pembuluh darah otak sehingga terjadi iskhemik otak, bahkan dapat terjadi keadaan cerebro vaskuler accident atau stroke yang diikuti dengan kelumpuhan separo anggota tubuh atau seluruhnya. Menurut Imam Parsudi (dikutip Boedhi Darmojo), hipertensi dapat menimbulkan kelainan pada otak yang berupa:

1. Infarik serebri sebagai akibat thrombus atau emboli.

2. Perdarahan intracranial dengan segala akibatnya.

3. Ensefalopati hipertensif.

\section{Pengaruh Terhadap Ginjal}

Hipertensi dapat menyebabkan perubahan-perubahan pada perenkhim ginjal yang berakibat kegagalan ginjal. Gagal ginjal ini dapat diketahui dengan melihat kadar kreatinin darah sangat meningkat dan proteinuria. Keterkaitan antar hipertensi dan ginjal nampaknya merupakan dua keadaan yang tidak bisa dipisahkan. Penyakit ginjal dapat menyebabkan timbulnya hipertensi, dan hipertensi sendiri dapat menyebabkan kerusakan pada glomerulus bahkan sampai pada kegagalan ginjal. 
Menurut Mulvany, adanya perubahan struktural pada pembuluh darah ginjal kemungkinan disebabkan adanya mekanisme sebagai berikut: tingginya tekanan darah akan menyebabkan timbulnya kerusakan dinding pembuluh ginjal, termasuk pula kerusakan pembuluh glmerulus dan hal ini secara progresif mengurangi jumlah nefron yang berfungsi baik dengan berjalannya waktu. Karena terdapat penurunan jumlah nefron yang aktif, maka fungsi tersebut diambil alih oleh nefron yang lain untuk mempertahankan fungsi ginjal. Tetapi nefron yang bekerja lebih keras ini lama-lama akan mengalami sklerotik sehingga makin banyak nefron yang mengalami keruskan, dan laju ini akan bertambah lagi bila tekanan darahnya tinggi. Jadi pengatuh hipertensi pada ginjal adalah insufisiensi ginjal kronis dan gagal ginjal kronis.

\section{Pengaruh Pada Mata}

Hipertensi dapat menyebabkan kelainan pada mata berupa retinopati hipertensif. Dengan funduskopi tampak adanya perdarahan retina dengan atau tanpa adanya papil udema.

MEDIKORA Vol. IV, No 2, Oktober 2008: 1-18 


\section{Perawatan Hipertensi}

Tujuan perawatan/pengobatan penderita hipertensi adalah untuk mencegah morbiditas atau mortalitas yang merupakan komplikasi dari hipertensi dan nyata-nyata sangat merugikan penderita.

Dr. Cleaves Bennett (dikutip Soen I Siauw, 1994;133) berpendapat bahwa dengan merubah gaya hidup maka penderita hipertensi akan memperoleh manfaatnya yaitu dengan cara mengubah pola makan, menurunkan berat badannya, latihan olahraga yang teratur, mengurangi stress dan selalu mengontrol tekanan darahnya.

Menurut Imam Parsoedi (dikutip Boedhi Darmojo, 1989;77) perawatan hipertensi dibedakan atas terapi tanpa obat dan terapi dengan obat. Terapi tanpa obat digunakan sebagai tindakan definitif untuk hipertensi ringan dan sebagai tindakan suportif pada hipertensi sedang dan berat.

Acuhan yang banyak dipakai untuk terapi tanpa obat sampai sekarang masih ada perbedaan tetapi tidak prinsip, pada dasarnya terapi tanpa obat adalah meliputi:

1. Penurunan berat badan untuk seberat $1 \mathrm{~kg}$ akan menurunkan tekanan darah kira-kira sebesar 2,5/1,5 $\mathrm{mmHg}$. 
2. Pembatasan masukan garam dapat menurunkan tekanan darah sebesar 10/5 $\mathrm{mmHg}$.

3. Bagi peminum alkohol harus membatasi atau menghentikan sama sekali.

4. Dilarang merokok atau mengehentikan merokok.

5. Melakukan olahraga aerobic seperti jalan cepat, jogging, bersepeda dan renang.

6. Relaksasi, tujuannya mengendalikkan emosi supaya lebih sabar tidak mudah marah.

7. Diet rendah lemak jenuh dan tinggi lemak tak jenuh.

8. banyak makan sayuran atau buah-buahan selama faal ginjal normal.

Untuk hipertensi sedang dan berat harus dikombinasikan terapi tanpa obat dan terapi dengan obat untuk memperoleh hasil yang optimal dari pengobatan tersebut. Harus dimaklumi dan dimengerti oleh penderita hipertensi bahwa dengan pengobatan kombinasi di atas kadang-kadang tidak seperti yang diharapkan penderita. Disamping itu pada hipertensi primer ada kecenderungan tekanan darah akan naik lagi setelah pengobatan, sedangkan pada hipertensi sekunder kira-kira sepertiga dari penderita mengalami kesulitan mengembalikan tekanan darahnya kearah normal seperti sebelum sakit.

MEDIKORA Vol. IV, No 2, Oktober 2008: 1-18 
Obat-obat anti hipertensi diusahakan memenuhi syarat sebagai berikut: efek penurunan tekanan darah efektif, efek sampingan sedikit atau tidak ada, cara pemberiannya sederhana dapat peroral dan harga relatif murah serta mudah dijangkau masyarakat.

\section{KESIMPULAN DAN SARAN}

Dari uraian di atas tersebut dapat ditarik beberapa kesimpulan tentang hipertensi yaitu:

1. Seseorang dikatakan menderita hipertensi bila tekanan sistolenya $160 \mathrm{mmHg} /$ atau lebih dan atau tekanan diastolenya $95 \mathrm{mmHg} /$ lebih.

2. Berdasarkan penyebabnya hipertensi ada dua macam yaitu hipertensi primer dan sekunder, sedang pembagian atas dasar berat ringannya dibagi menjadi hipertensi ringan, sedang dan berat.

3. Hipertensi dapat menyebabkan komplikasi pada jantung, otak, ginjal dan mata bahkan dapat menyebabkan kematian mendadak pada penderita.

4. Pengobatan hipertensi ringan dengan terapi tanpa obat sedangkan untuk hipertensi sedang dan berat dilakukan kombinasi terapi tanpa obat dan terapi dengan obat.

Hipertensi dan Pengaruhnya Terhadap Organ-Organ.. (dr. Moch Noerhadi) 


\section{SARAN}

Mengingat komplikasi hipertensi yang sangat merugikan penderita dan sulitnya mengobati hipertensi perlu aturan-aturan tertentu bagi penderita hipertensi:

1. Penderita hipertensi harus disiplin memeriksakan tekanan darahnya untuk mendapatkan pengobatan.

2. Penderita harus yakin betapapun hipertensi sulit sekali disembuhkan tetapi dapat dikendalikan.

3. Bila dirasakan adanya gejala yang berkaitan dengan hipertensi harus segera periksa kedokter untuk menjaga hal-hal yang tidak diinginkan yang datang secara mendadak.

4. Sedapat mungkin tindakan terapi dimasukkan dalam cara hidup penderita.

5. Mengikutsertakan keluarga penderita dalam proses terapi.

MEDI KORA Vol. IV, No 2, Oktober 2008: 1-18 


\section{DAFTAR PUSTAKA}

Boedhi Darmojo. (1989). HIPERTENSI, Pengelolaan secara menyeluruh. Semarang: IDI Wilayah Jateng.

Ezra A. Amsterdam. MD., Jack H. Wilmore. PhD., Anthony N. MD. (1978). Exercise in Cardiovascular Health and Disease. New York: Yorke Medical Books.

Fox, E.L., Kirby T.E., Fox, A.R.. (1986). Bases of Fitness. New York: Macmillan Publishing Company.

Moerdowo, FRSA. (1984). Masalah Hipertensi. Jakarta: Bharata Karya Aksara.

Norman m. Kaplan, MD., Jremiah Stamler, MD. (1986). Prevention of Coronary Heart Disease, Practical Management of The Risk Factors. Philadelphia: W.B. Saunders Co.

Soen I. Siauw. (1994). Tekanan Darah Tinggi atau Hipertensi. Solo: PT. Dabara Bengawan.

Soeparman. DR., Sarwono Waspadji. (1987). Ilmu Penyakit Dalam Jilid I. Jakarta: Balai Penerbit FKUI.

Soeparman. DR., Sarwono Waspadji. (1990). Ilmu Penyakit Dalam Jilid II. Jakarta: Balai Penerbit FKUI. 